\title{
Local Evaluation Criteria for Global Textbooks: A Case Study from Iran
}

\author{
Mehdi Karamifar \\ Faculty of Foreign languages, University of Isfahan, Iran \\ Hossein Barati \\ Faculty of Foreign languages, University of Isfahan, Iran \\ Manijeh Youhanaee \\ Faculty of Foreign languages, University of Isfahan, Iran
}

\begin{abstract}
The fact that ELT textbooks play a crucial role in most EFL/ESL settings around the globe may not be rebuffed. This role is noticeably pivotal in language institutes in Iran where global textbooks determine much of what happens in classrooms. It is therefore crucial to know how well a textbook plays the role it is assumed to do. When decisions are to be made about selecting a proper textbook for a specific teaching situation, the idea of textbook evaluation comes true. To conduct a worthwhile evaluation of textbooks, which are supposedly "the main teaching and learning aid" (Matthews, 1985, p.202), one needs to have some criteria against which textbooks could be evaluated. This study was an attempt to set some textbook evaluation criteria based on the ideas of teachers and students who used global textbooks in language institutes of Isfahan, Iran. To do so, the researcher conducted interviews with 15 teachers and 15 students in order to find out what they thought of the textbooks they were teaching and/or learning. The data gathered from the interviews showed the specifications teachers and students take into account when judging their textbook. Finally, based on the interviews two local questionnaires were developed.
\end{abstract}

Index Terms - textbook, evaluation criteria, questionnaire

\section{INTRODUCTION}

Textbook evaluation is an important process which can be beneficial to publishers, teachers as well as students. As Amrani (2011) asserts, publishers have always needed to evaluate their materials in order to satisfy a wide range of end users. Except for publishers, teachers also need to evaluate teaching materials for a variety of reasons. To begin with, evaluation helps the selection of an appropriate textbook. The pivotal role textbooks play emphasizes the proper selection of textbook for a class. Furthermore, sometimes there is the need to adopt new textbooks through evaluation. As Sheldon (1988) declares, "the selection of a coursebook signals an executive educational decision in which there is considerable professional, financial and even political investment" (p. 237).

As discussed above, textbook evaluation is an important process which, as noted by Hargreaves (1989), is sometimes neglected. However, it should be noted that the evaluation process is actually of secondary importance to the criteria against which textbooks are evaluated. Using a checklist is the most common form of textbook evaluation and a number of scholars have proposed different evaluation checklists. For instance, Cunningsworth (1995) introduces a checklist comprising of what he believes to be the most essential general criteria. His checklist covers various areas such as aims and approaches, design and organization, etc. A number of other scholars and researchers such as Chastain (1971), Tucker (1975), Daoud and Celce-Murcia (1979), Canlin and Breen (1979), and Sheldon (1988) have also attempt to come up with their own evaluation checklist.

Littlejohn (2011) presents a framework different from the evaluation checklists available. Although he agrees that such frameworks can be useful depending on the purpose you have in evaluating materials, Littlejohn suggests that we need a general framework through which materials can 'speak for themselves'. Littlejohn (2011) proposes a framework which provides a list of the aspects that need to be considered from a pedagogic viewpoint. His framework is divided into two parts: publication and design. The first section concerns the 'tangible' or 'physical' aspects of the materials while the second section relates to the thinking underlying the materials.

On the other hand, some language practitioners and researchers believe that since instructional settings are uniquely different we need different evaluation schemes as well. As an instance, McDonough and Shaw (2003) suggest that they can't certainly set worldwide criteria for evaluation since some might argue that textbook criteria are often local. Moreover, Byrd (2001, p.416) states "making a comprehensive yet reasonable checklist for evaluation of textbooks is an enormous challenge that requires different lists for different types of courses in different settings." Bearing this in mind, the researcher in the present study made an attempt to come up with local evaluation criteria against which ELT textbooks could be evaluated. 


\section{LITERATURE REVIEW}

Mukundan, Hajimohammadi and Nimehchisalem (2011 a) set out to design a tentative evaluation checklist by considering matters of validity, reliability and practicality. To ensure the validity of their checklist, they tried to follow the guidelines provided by similar previous studies. In order to have a reliable checklist, they tried to avoid large, vague and dogmatic questions by providing items which are understandable for the novice evaluators. They took into account matters of practicality by following Cunningsworth's (1995) suggestion. "It is important to limit the number of criteria used, the number of questions asked, to manageable portions, otherwise we risk being swamped in a sea of details." (Cunningsworth, 1995, p.5).

In a later study, Mukundan et al (2011 b) made an attempt to refine the English language textbook evaluation scheme that they had previously developed. At the first stage of this study, the focus group which consisted of 6 PhD candidates participated in an unstructured interview in which the participants were free to express their ideas on the inclusion or exclusion of items in the checklist. At the second stage, each participant was given a copy of the checklist and was asked to reword, delete, or add items where necessary. Their research resulted in a 36-item textbook evaluation scheme.

Soori, Kafipour and Soury (2011) made an effort to evaluate the first grade English textbook used in Iran's senior high school. Before embarking on the evaluation, the researchers developed a set of universal characteristics of EFL textbooks to conduct the evaluation.

Also, Razmjoo (2010) intended to develop and design a textbook evaluation scheme for the expanding circle. To do so, 30 male and female TEFL instructors were selected. Semi-structured interviews were then conducted with the teachers during which they provided answers to some open-ended questions. The researches then codified and categorized the data gathered from the interviews. The result of this investigation was an evaluation scheme consisting of 6 main factors containing 41 items.

Moreover, Miekley (2005) sought to come up with a valuable tool for evaluating EFL/ ESL reading textbooks. The newly developed checklist was mainly based on previous checklists available and/or recent research. The checklist fell into two major sections, one pertaining to the textbook itself and the other part pertaining to the teacher's manual. Other scholars such as Rahimpour and Hashemi (2011), Nahrkhalaji (2012) etc., also made attempts to come up with some form of evaluation checklists.

\section{PURPOSE OF THE STUDY}

This study was an attempt to design two questionnaires based on the interviews done with teachers and students who are teaching and/ or learning English in language institutes in Isfahan, Iran. The need for local criteria has been emphasized by a number of scholars (Roberts, 1996; Byrd, 2001; McDonough and Shaw, 2003) who argue that for different instructional settings we need different evaluation criteria. This study was to find out what criteria teachers and students take into consideration when asked to evaluate or voice their opinion regarding the ELT textbook they use.

\section{METHODOLOGY}

\section{A. Participants}

The participants of this study were fifteen teachers and fifteen students in the language institutes of Isfahan. In other words, a total number of thirty teachers and students, both male and female, were interviewed and asked to comment on each of the ELT textbooks they used. It should be noted that Top Notch, Interchange $3^{\text {rd }}$ edition, and Four Corners were being used in the language institutes under study. All the participants agreed to attend the interview sessions voluntarily. The participants were selected via availability sampling which means the researcher selected whoever was available and willing to take part in the interviews (Farhady, 2001).

\section{B. Instruments}

The instrument for data collection in this study was interview questions. The researcher held interviews with the teachers and the students in order to find out what they thought of the textbooks. The data gathered helped this study to establish local criteria for textbook evaluation.

\section{Data Collection}

Semi-structured interviews were preferred since they were flexible, adhered more to the agenda and also gave the interviewees enough freedom to express their ideas (Mackey and Gass, 2005). The researchers showed up in each of the language institutes and interviewed the participants. The interview sessions were conducted in Persian. With the prior permission of the participants, the interview sessions were voice-recorded and later transcribed. Each interview session lasted for approximately 25 minutes in which the teachers and students discussed their ideas on the EFL textbooks they used and/or studied.

During the interview sessions, the participants were asked to provide complete answers to a number of open-ended questions. The general guidelines for the interview questions were taken from previous studies (e.g. Cunningsworth 1995, Daoud and Celce-Murcia 1979, Rivers 1981, Sheldon 1988, Skierso 1991, McDonough and Shaw 2003, etc.). 
The researcher established a set of questions to seek teachers' and students' ideas on the ELT textbooks they used. Table 1 presents the questions which were used as a point of departure for the interviews.

TABLE 1.

QUESTIONS FOR THE INTERVIEW PHASE OF THE STUDY

Questions for the interviews
1- What do you think of the appearance and general design of the textbook?
2- How have language skills (listening, speaking, reading and writing) been dealt with in the textbook?
3- How has language content (vocabulary, grammar, pronunciation) been dealt with?
4- What problems did you have while teaching/learning this textbook?
5- How can this textbook be improved?

\section{RESULTS AND ANALYSIS}

As said above, in order to establish local evaluation criteria for ELT textbook, semi-structured interviews were conducted with 15 teachers. The teachers were asked 5 general questions (see Table 1). The following are the English versions of the extracts taken from these interviews.

Extract 1. Teachers' answers to the first question of the interview

1. *I. What do you think of the appearance and general design of the textbook?

2. *T1. In my opinion the pictures and appearance [of the textbook] enjoy good quality ... I mean in some lessons pictures are used, for example, to show colors or feelings, such pictures are understandable to the students ... I think there are enough pictures [in the textbook] and ... but I think some adults don't like cartoon pictures ... I think 70 percent of the pictures are suitable for adults.

3. T2. I think this book has the best design in terms of the information presented on each page somehow it is very well organized and I think it is not confusing

4. T3. I think the pictures in this book are attractive to the students ... I mean for their age. Some pictures are censored because of cultural differences. But in terms of sequencing the content this is one of the positive points about this book. Right now I teach different books and I think this book has the best sequence. I think I can say its arrangement is better than other books.

$$
\begin{gathered}
\text { *I: Interviewer } \\
\text { *T: Teacher } \\
\text { [ ] more information } \\
\text {... Omission }
\end{gathered}
$$

Extract 2. Teachers' answers to the second question of the interview

1. I. How have language skills such as listening, speaking, reading and writing been dealt with in the textbook?

2. T1. some of the speaking topics are not interesting to students or they don't have enough information to talk, because they are mostly high school students ... But the listening exercises are good because they get familiar with different accents, sometimes a Chinese speaks ... some might consider this a drawback but I think it's good they hear different accents. The listening contents are also good and related to the topics. The readings sometime contain very difficult words. If you see the book, sometimes the texts are exactly like original magazines and newspaper and I think it's good

3. T2. the readings ... well there are good readings in terms of the grammar, I mean the grammar of the unit is again shown in the reading even sometimes the grammar of previous units are reviewed in the reading. In general the readings were ok, but I think it would have been better if there were more reading exercises.

4. T3. ... by the way I think the writings in Interchange are better than Four Corners because it completely teaches writing in one page ... [it] teaches the students how to write topic sentences and how to write a paragraph, but Four Corners is not like this ... In term s of reading also I think it is much better ... the texts are long enough to engage students and improve their reading ability, although the level of listening exercises is low for students. For example, I had a class the other day and ... well the listening was not difficult but it was too long and I think the students, you know, were bored, it was very long.

Extract 3. Teachers' answers to the third question of the interview

1. I. How has language content (i.e. vocabulary, grammar and pronunciation) been dealt with?

2. T1. I think it's a good book in terms of grammar, the sequence is good. For example, the students learn present perfect then present perfect continuous. However, there are not [enough] exercises. There are exercises in the workbook but we need [grammar] exercises in the lessons. For example, after teaching passive voice there are few exercises for students which is not enough so we have to rely on other sources for students to practice passive voice. This book has a high quality CD and students can listen to the CD at home and work on their pronunciation but phonetics is not well presented in the book ... there are just exercises for making contractions. That is again not enough.

3. T2. I think there is enough explanation on grammar and it's good, there are examples for each grammatical structure, too ... about the vocabulary, for example, in one section just some pictures are used to teach different movie genres and the pictures are not very clear. I think if there were some explanations too, it could be better. I think if the new words were again used in the reading passages, students could learn them better because there are not enough exercises for vocabulary practice.

4. T3. This book has paid lots of attention to pronunciation and sentence stress. This is one of the advantages of this book ... the grammar is presented briefly and in each unit few grammatical points are discussed. Therefore it's not confusing for the students. They go ahead step by step. Although, there are few exercises for students ... Another problem is that some new words in the unit don't suit the level of students. For example, it's difficult for beginner students to pronounce or learn the word quadriplegic; they don't need to learn this word at this level at all.

Extract 4. Teachers' answers to the fourth question of the interview 


\begin{abstract}
1. I. What problems did you have while teaching this textbook?
2. T1. One of the problems with this book is that it really needs experienced teachers. The teachers' book is also very impor tant. If you give me this book to teach without help from the teachers' book I would surely face many problems. Not every teacher can teach this book, but the good thing is that we can use different methods to teach it.

3. T2. There were some cultural issues that I wasn't familiar with or some other issues that I didn't have information about, but fortunately some of these issues are explained in the teachers' book and I learned a lot. Although in some aspects the teachers' book is not very practical. For example, the timing given for exercises is not useful at all.
\end{abstract}

Extract 5. Teachers' answers to the fifth question of the interview

\title{
1. I. How can this book be improved?
}

2. T1. I think the book would be much better if there were more exercises for grammar, and also I think the topic of some units doesn't interest the students. Perhaps because they don't like the topics or they don't have enough information about the topics.

3. T2. I think there is too much new information presented on each page, they need to remove this problem. Besides, there is too much repetition of the same topic for discussion. I mean students have to talk about the same subject for 2 or 3 sessions and they get pretty bored.

4. T3. A problem I think is that it [the book] takes too much energy from the teacher; you know the teacher has to do everything in class and the students are very inactive. I think a good book should engage the students more ... also I think longer passages would have been better.

Extracts 1, 2, 3, 4 and 5 illustrate some of the responses provided by teachers for the 5 questions of the interview. Having analyzed and categorized all the voice-recorded interviews, the researcher found out that there were certain features in the textbooks which most teachers paid attention to when evaluating them. For example, most teachers in the interviews pointed out that a good textbook should enjoy clear and illustrative pictures, the appearance of the textbook should attract language learners, there should be enough exercises for grammar and listening, there should be a good teachers' book accompanying the textbook and so forth.

The same procedure was followed to establish a set of textbook evaluation criteria which were important to the students. To do so, interviews were conducted with 15 students. Throughout the interviews, students were asked 5 general questions (see Table 1) and they responded to the questions. The following are English translation of some short extracts taken from these interviews.

Extract 1. Students' answers to the first question of the interview

\section{1. *I. What do you think of the appearance and general design of the textbook?}

2. *S1. There are various pictures in the textbook; the pictures are good and enjoy high quality. The pictures don't make me tired or bored. Sometimes the pictures are not much related to the text or conversation but in general they are OK. I like the pictures because there are both cartoon pictures and real pictures.

3. S2. The book in my opinion is attractive and the pictures are good, for example the pictures are related to the new words, for example about sports... there are good pictures. I don't feel that the pictures are too childish.

4. S3. The pictures are good, but I think a problem is that the pictures distract us from the lesson because they are really flashy ... I understand what each picture wants to say or what message it wants to convey. I think the design of the book attracts students.

$$
\begin{gathered}
* \text { I: Interviewer } \\
\text { *S: Student }
\end{gathered}
$$

Extract 2. Students' answers to the second question of the interview

\begin{abstract}
1. I. How have language skills such as listening, speaking, reading and writing been dealt with in the textbook?
2. S1. I don't like the speaking sections because there are only repeated questions and we don't talk about different things ... I feel we are weak in listening skill and there should be more exercises for listening practice. Also, there should be newer passages which are more related to the lesson ... the writing sections are good because they help us practice the new words and also improve our writing, I am satisfied with them.

3. S2. I feel that my English has improved a lot with this book. I can speak well and the exercises in the book are enough ... sometimes the listening sections are difficult for me and they are too long. There are new words in passages and I like learning them.

4. S3. I think there should have been more discussion sections for speaking practice. The readings are good and I like them but I am really weak in writing. The book doesn't tell us how we should write and it's a big problem I think.
\end{abstract}

Extract 3. Students' answers to the third question of the interview

1. I. How has language content (i.e. vocabulary, grammar and pronunciation) been dealt with?
2. S1. I love the vocabulary sections but the explanations provided for grammar sections are very short. I think we should practice grammar
more ... There are few exercises for pronunciation too.
3. S2. We learn very few new words in each unit and we don't learn about idioms but the grammar section was good because there were some
good examples and simple explanations ... I think there are sufficient exercises for vocabulary but for grammar we need more practice.
4. S3. Our teacher tells us about phonetics sometimes but the book provide us with no explanation on them, I think we need some pronunciation
practice ... Sometimes I don't understand the new words and I think it would have been better if there had been more explanation about the
words.

Extract 4. Students' answers to the fourth question of the interview

1. I. What problems did you have while learning this textbook?

2. S1. The listening sections are sometimes too long and boring for me ... and some of the new words are not really useful for me ...

3. S2. I learned many new words in this book but I don't know how I should use these words. There are always too many mistak es in my writing ... the questions in speaking section are difficult for me and sometimes I don't even know what to say in Persian let alone in English.

4. S3. Sometimes there are words for strange foods or customs that I know nothing about. They are related to the cultures of other countries ... sometimes it's good to learn about other cultures but sometimes it really confuses me. 
Extract 5. Students' answers to the fifth question of the interview

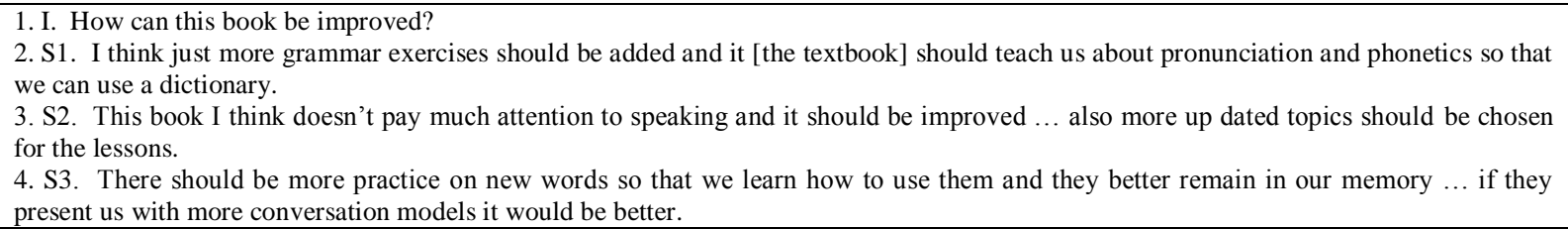

Extracts 1, 2, 3, 4 and 5 illustrate some of the responses provided by students for the 5 questions of the interview. The participants of the interviews were free to ask for further explanation whenever they did not understand the questions. The data gathered from all the students were analyzed and categorized. Then, based on these data a 25 -item questionnaire was developed (see appendix B). The questionnaire tries to address the points that students mentioned while evaluating their ELT textbook.

\section{DISCUSSION}

Having conducted interviews with teachers and students, the researcher then made an attempt to develop two questionnaires for both students and teachers. The questionnaire developed for teachers comprised 40 items which fell into 10 clusters (see Table 2). The items were developed based on what the teachers said while evaluating the ELT textbooks they used.

TABLE 2

ITEMS ON TEACHER'S QUESTIONNAIRE

\begin{tabular}{|l|l|}
\hline Item specification & Number of Items \\
\hline Items related to design and appearance & $\begin{array}{l}1-4-5-6-8 \\
\text { (Cluster 1) }\end{array}$ \\
\hline organization & $\begin{array}{l}2-3-7 \\
\text { (Cluster 2) }\end{array}$ \\
\hline speaking & $\begin{array}{l}9-10-11 \\
\text { (Cluster 3) }\end{array}$ \\
\hline listening & $\begin{array}{l}12-13-14-15-16 \\
\text { (Cluster 4) }\end{array}$ \\
\hline reading & $17-18-19-20$ \\
& (Cluster 5) \\
\hline writing & $21-22-23$ \\
& (Cluster 6) \\
\hline vocabulary & $24-25-26-27-28$ \\
& $($ Cluster 7) \\
\hline cultural issues & 29 \\
\hline grammar & $30-31-32$ \\
& (Cluster 8) \\
\hline pronunciation & $33-34-35$ \\
& $($ Cluster 9) \\
\hline student centeredness & 36 \\
\hline supplementary sources & 37 \\
\hline teaching methods & 38 \\
\hline teacher's book & $39-40$ \\
& $($ Cluster 10) \\
\hline
\end{tabular}

The questionnaire for students consisted of 25 items -7 clusters- which addressed different issues and aspects related to ELT textbooks. Table 3 shows the categorization of items on students' questionnaire. 
TABLE 3.6.

ITEMS ON STUDENT'S QUESTIONNAIRE

\begin{tabular}{|l|l|}
\hline Item specification & Number of Items \\
\hline Items related to design and appearance & $\begin{array}{l}1-2-3-4-5 \\
\text { (Cluster 1) }\end{array}$ \\
\hline speaking & $\begin{array}{l}6-7-8 \\
\text { (Cluster 2) }\end{array}$ \\
\hline listening & $\begin{array}{l}9-10-11 \\
(\text { Cluster 3) }\end{array}$ \\
\hline reading & $\begin{array}{l}12-13-14 \\
(\text { Cluster 4) }\end{array}$ \\
\hline writing & $15-16$ \\
& $($ Cluster 5) \\
\hline vocabulary & $17-18-19$ \\
& $($ Cluster 6) \\
\hline grammar & $20-21-22$ \\
& $($ Cluster 7) \\
\hline pronunciation & 23 \\
\hline topics of units & 24 \\
\hline aims of students & 25 \\
\hline
\end{tabular}

The clusters (see Table 2 and 3) suggest that the findings of this research are to some extent in line with the previous studies outlined in section II of this paper. However, certain differences are observable too. To begin with, using technical words and jargons in an evaluation scheme might be easily discernible for an expert; however, they might not be clear enough for students and teachers with low expertise. Thus, one of the merits of the two questionnaires in this study was that the type of language and the terminologies employed suited the teachers and students since they are taken from the interviews. Furthermore, both students and teachers mentioned different aspects of the textbooks they used. However, as Cunningsworth (1995) suggests, it is best to keep the number of items to manageable portions. Therefore, from the different issues mentioned in the interviews, only the ones which were recognized by a larger number of teachers or students were addressed in the two questionnaires. Finally, this study was an attempt to come up with two local evaluation questionnaires for both students and teachers separately.

\section{CONCLUSION}

As some scholars (e.g. Byrd, 2001; Sheldon, 1998) have argued, textbook evaluation criteria are context-dependent. Besides, specific needs of the teachers and students should be considered. The present study was an attempt to develop local evaluative criteria which could be used for ELT textbook. In so doing, interviews were held with teachers and students in language institutes of Isfahan. Having transcribed and categorized all the interviews, the researcher developed two questionnaires; one for teachers and one for students (see appendices A and B). The criteria addressed in the questionnaires were to some extent similar to the criteria identified by the previous researcher, there were some differences, though. At the end, it should be noted that textbook evaluation is an ongoing process and as Sheldon (1988, p.245) notes, "materials evaluation is fundamentally a rule-of-thumb activity and that no formula, grid or system will ever provide a definite yardstick."

APPENDiX A. TEACHERs' Questionnaire

\begin{tabular}{|c|c|c|c|c|c|}
\hline & $\begin{array}{l}\text { Completely } \\
\text { agree }\end{array}$ & agree & disagree & $\begin{array}{l}\text { Completely } \\
\text { disagree }\end{array}$ & $\begin{array}{l}\text { No } \\
\text { idea }\end{array}$ \\
\hline \multicolumn{6}{|l|}{ 1-The pictures of the book are clear and illustrative. } \\
\hline \multicolumn{6}{|l|}{ 2-The sequencing of content enjoys good variety. } \\
\hline \multicolumn{6}{|l|}{ 3- The content is arranged from easy to difficult. } \\
\hline \multicolumn{6}{|l|}{ 4- The number of pictures is enough for teaching purposes. } \\
\hline \multicolumn{6}{|l|}{ 5- The pictures are suitable regarding the age of the students } \\
\hline \multirow{2}{*}{\multicolumn{6}{|c|}{$\begin{array}{l}\text { 6- The appearance of the book attracts the students. } \\
\text { 7- There is sufficient information presented on each page of the book. }\end{array}$}} \\
\hline & & & & & \\
\hline \multicolumn{6}{|l|}{ 8- The pictures are up to date and of good quality. } \\
\hline \multicolumn{6}{|l|}{ 9- The textbook pays enough attention to speaking skill. } \\
\hline \multicolumn{6}{|l|}{ 10- Speaking topics are interesting and various. } \\
\hline \multicolumn{6}{|l|}{ 11- Speaking topics are related to the background knowledge of the students. } \\
\hline \multicolumn{6}{|l|}{ 12- There are enough exercises for listening. } \\
\hline \multicolumn{6}{|l|}{ 13- Listening exercises familiarize students with a variety of accents. } \\
\hline \multicolumn{6}{|l|}{ 14- The length of the listening exercises suites the class time available. } \\
\hline \multicolumn{6}{|l|}{ 15- The difficulty level of the listening exercises matches the level of students. } \\
\hline \multicolumn{6}{|l|}{$\begin{array}{l}\text { 16- The questions which follow each listening section increases students' focus } \\
\text { on the listening content. }\end{array}$} \\
\hline \multicolumn{6}{|l|}{ 17- There are enough exercises for reading comprehension in the textbook. } \\
\hline 18- The length of the reading passages matches the level of the students. & & & & & \\
\hline
\end{tabular}




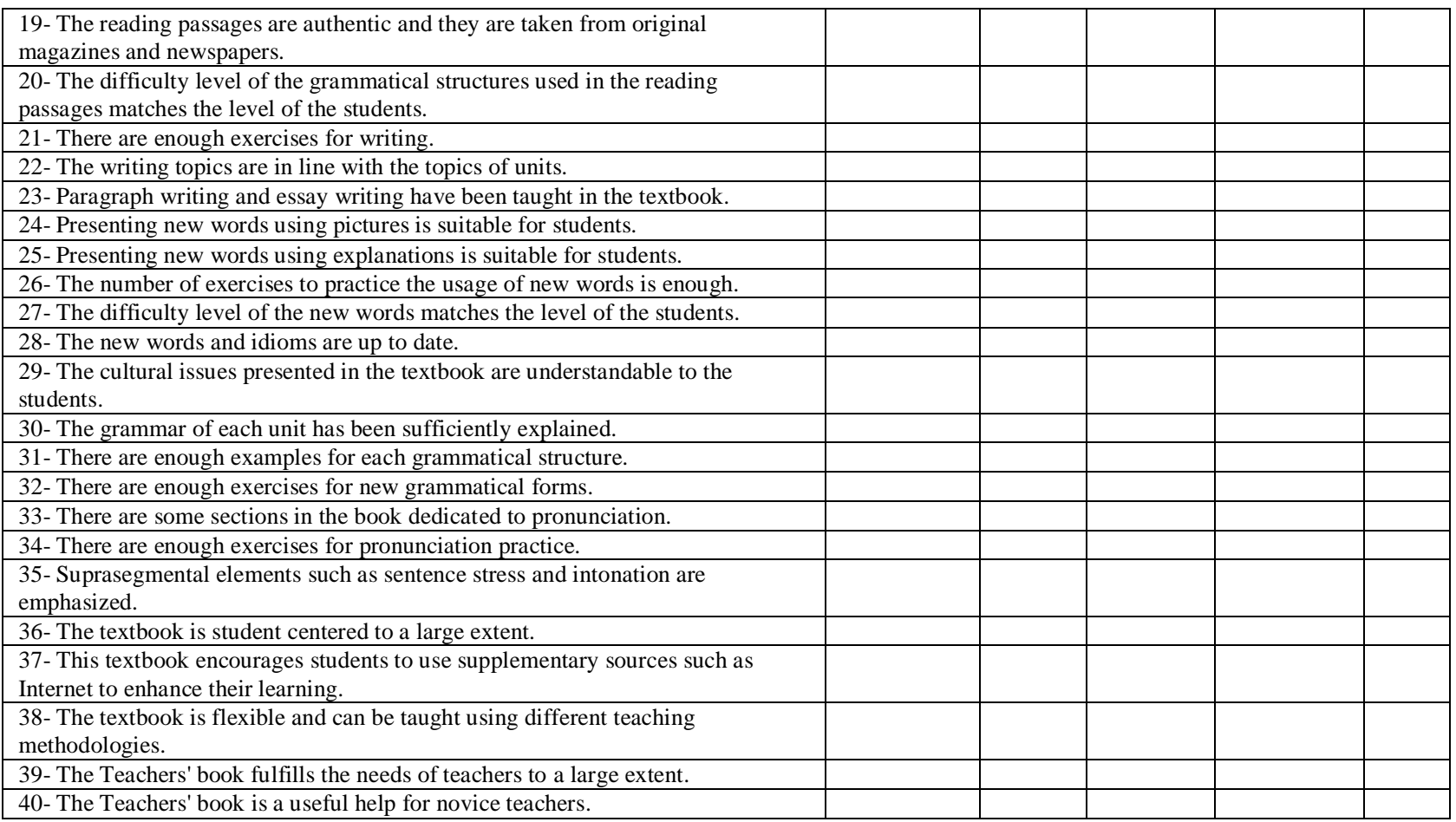

\section{APPENDix B. STUdents' QuestionnAire}

\begin{tabular}{|c|c|c|c|c|c|}
\hline & $\begin{array}{l}\text { Completely } \\
\text { agree }\end{array}$ & agree & disagree & $\begin{array}{l}\text { Completely } \\
\text { disagree }\end{array}$ & $\begin{array}{l}\text { No } \\
\text { idea }\end{array}$ \\
\hline 1- I like the pictures in the textbook. & & & & & \\
\hline 2- The pictures explaining the new words are clear. & & & & & \\
\hline 3- The pictures of the conversation sections are clear. & & & & & \\
\hline 4- The appearance of the textbook motivates me to study more. & & & & & \\
\hline 5- I think the pictures help me better retain the information. & & & & & \\
\hline 6- Through this book, my speaking skill has satisfactorily improved. & & & & & \\
\hline 7- There are various topics for speaking practice. & & & & & \\
\hline 8- Group discussion sections helped me improve my speaking. & & & & & \\
\hline 9- I have no problem understanding the listening sections. & & & & & \\
\hline 10- The listening sections familiarize me with different accents. & & & & & \\
\hline 11- I think I do not need more listening practice. & & & & & \\
\hline 12- I think that the reading passages are in line with the topics of units. & & & & & \\
\hline 13- The reading passages helped me extend my range of vocabulary. & & & & & \\
\hline 14- Through this book, my reading comprehension skill improved a lot. & & & & & \\
\hline 15- I like the writing topics in this textbook. & & & & & \\
\hline 16- This book helped me a lot to improve my writing skill. & & & & & \\
\hline 17- Repetition of the new words helped me learn them better. & & & & & \\
\hline 18- Using pictures to present new words helped me learn them better. & & & & & \\
\hline 19- I think I leaned many practical and useful words in each unit. & & & & & \\
\hline 20- In my opinion, grammar is sufficiently explained in this book. & & & & & \\
\hline $\begin{array}{l}\text { 21- The examples in the grammar sections helped me better learn the } \\
\text { grammar. }\end{array}$ & & & & & \\
\hline 22- I think I do not need more grammar practice. & & & & & \\
\hline $\begin{array}{l}\text { 23- This textbook helped me a lot in learning the correct pronunciation } \\
\text { of words and sentences. }\end{array}$ & & & & & \\
\hline 24- I like the topics of units. & & & & & \\
\hline $\begin{array}{l}\text { 25- Since each student has a special purpose for learning English, this } \\
\text { textbook helped me realize my goals. }\end{array}$ & & & & & \\
\hline
\end{tabular}

\section{REFERENCES}

[1] Amrani, F. (2011). The process of evaluation: a publisher's view. In Tomlinson, B. (Ed.), Materials development in language teaching. Cambridge: Cambridge University Press, 267-295.

[2] Byrd, P. (2001). Textbooks: Evaluation for selection and analysis for implementation. In M. Celce-Murcia, Teaching English as a second or foreign language ( $\left.3^{\text {rd }} \mathrm{edn}\right)$. US: Heinle \& Heinle, Thomsom Learning Inc, 415-427. 
[3] Candlin, C.N. \& Breen, M.P. (1979). Evaluating, adapting and innovating language teaching materials. In C.Yorio, K.Perkins and J. Schacter (Eds.). On TESOL: The learner in focus. Washington, D.C.:Teachers of English to speakers of other languages.

[4] Chastain, K. (1971). The development of modern language skills: theory to practice. Philadelphia The center for Curriculum Development, Inc.

[5] Cunningsworth, A. (1995). Choosing your coursebook. Oxford: Heinemann Publishers Ltd.

[6] Daoud, A. \& Celce-Murcia, M. (1979). Selecting and evaluating a textbook. In M. Celce-Murcia and L. McIntosh (Eds.), Teaching English as a second or foreign language. Cambridge, MA: Newbury House Publishers, 302-307.

[7] Farhady, H. (2001). Research Methods in Applied Linguistics. Payame Noor University.

[8] Hargreaves, P. (1989). DES-IMPL-EVALU-IGN: an evaluator's checklist. In Johnson, R.K. (ed.) The second language curriculum. Cambridge University Press, 35-47.

[9] Littlejohn, A. (2011). The analysis of language teaching materials: Inside the Trojan Horse. In B. Tomlinson (2011), Materials Development in Language Teaching. (2nd edn). Cambridge University Press.

[10] Mackey, A. \& Gass, S.M. (2005). Second language research: methodology and design. Lawrence Erlbaum Associates, Inc.

[11] Matthews, A. (1985). Choosing the best available textbook. In A. Matthews, M. Spratt, and L. Dangerfield (eds.) At the chalkface. London: Edward Arnold, 202-206.

[12] McDonough, J. \& Shaw,C. (2003). Materials and methods in ELT: A teacher's guide. (2 ${ }^{\text {nd }}$ edn). Malden, MA: Blackwell Publishing Ltd.

[13] Miekley, J. (2005) ESL textbook evaluation checklist. The Reading Matrix. 5.2, 101-109. Retrieved on January, 2, 2014 from: $\mathrm{http} / / / \mathrm{www}$.readingmatrix.com/reading_projects/miekley/project.pdf

[14] Mukundan, J., Hajimohammadi, R. \& Nimehchisalem, V. (2011 a). Developing an English language textbook evaluation checklist. Contemporary Issues in Education Research, 4.6, 21-27.

[15] Mukundan, J., Nimehchisalem, V. \& Hajimohammadi, R. (2011 b). Developing an English language textbook evaluation checklist: A focus group study. International Journal of Humanities and Social Sciences, 1.12, 100-106.

[16] Nahrkhalaji, Sh. S. (2012). An Evaluation of a Global ELT Textbook in Iran: A Two-phase Approach. International Journal of Humanities and Social Science, 2.3, 184-191.

[17] Rahimpour, M. \& Hashemi, R. Textbook selection and evaluation in EFL context. World Journal of Education. 1.2, 62-68.

[18] Razmjoo, S. A. (2010). Developing a textbook evaluation scheme for the expanding circle. Iranian Journal of Applied Language Studies. 2.1, 121- 136.

[19] Rivers, W. (1981). Teaching foreign language skills. Chicago: University of Chicago Press.

[20] Roberts, J.T. (1996). Demystifying materials evaluation. System, 24.3, 375-389.

[21] Sheldon, L. E. (1988). Evaluating ELT textbooks and materials. ELT Journal, 42.4, 237-246.

[22] Skierso, A. (1991). Textbook selection and evaluation. In M. Celce-Murcia. Teaching English as a second or foreign language. (2nd Edn). Boston: Heinle \& Heinle Publishers, 432-453.

[23] Soori, A. \& Kafipour, R. \& Soury, M. (2011). EFL textbook evaluation and graphic representation. European Journal of Social Sciences, 26.3,481-493.

[24] Tucker, C.A. (1975). Evaluating beginning textbooks. English Teaching Forum, 13, 355-361.

Mehdi Karamifar was born in Isfahan, Iran, in 1989. He earned his BA degree in Translation Studies from University of Isfahan. He accomplished his MA degree in Teaching English as a Foreign Language (TEFL) at the University of Isfahan in 2013. His research interests include Language Assessment, Curriculum Planning, Textbook Evaluation and Discourse Analysis. He is currently teaching various BA courses at Amin Institute of Higher Education.

Hossein Barati is an assistant professor in TEFL at English Department, University of Isfahan, Iran. His areas of research include language testing \& assessment and research methodology in second/foreign language acquisition.

Manijeh Youhanaee holds a $\mathrm{PhD}$ in language and linguistics from the University of Essex. She has published a number of articles on the teaching/ acquisition of different English syntactic properties by native speakers of Persian. She teaches MA and PhD courses in linguistics, generative grammar, TEFL and SLA. Her areas of interest include syntactic theory, acquisition of L2 \& L3 syntax and issues in teaching and learning English as a second/foreign language 